\title{
Dichromatobolus, a new genus of spirobolidan millipedes from Madagascar (Spirobolida, Pachybolidae)
}

\author{
Thomas WESENER \\ Zoological Research Museum Alexander Koenig (ZFMK), Leibniz Institute for Animal Biodiversity, \\ Adenauerallee 160, D-53113, Bonn, Germany. \\ E-mail: t.wesener@leibniz-zfmk.de
}

urn:lsid:zoobank.org:author:86DEA7CD-988C-43EC-B9D6-C51000595B47

\begin{abstract}
A new genus, Dichromatobolus gen. nov., belonging to the genus-rich mainly southern hemisphere family Pachybolidae of the order Spirobolida, is described based on D. elephantulus gen. et sp. nov., illustrated with color pictures, line drawings, and scanning electron micrographs. The species is recorded from the spiny bush of southwestern Madagascar. Dichromatobolus elephantulus gen. et sp. nov. shows an unusual color pattern, sexual dichromatism with males being red with black legs and females being grey. Males seem to be more surface active, as mainly males were collected with pitfall traps. Females mainly come from the pet trade. The body of this species is short and very wide, being only 8 times longer than wide in the males. Live observations show the species is a very slow mover, digging in loose soil almost as fast as walking on the surface. The posterior gonopods of Dichromatobolus gen. nov. are unusually simple and well-rounded, displaying some similarities to the genera Corallobolus Wesener, 2009 and Granitobolus Wesener, 2009, from which the new genus differs in numerous other characters, e.g., size, anterior gonopods and habitus. Despite several attempts with fresh tissue samples and different primers, molecular barcoding did not work for Dichromatobolus gen. nov. Any relationships to the other 15 genera of Pachybolidae indigenous to Madagascar remain unknown.
\end{abstract}

Keywords. Biodiversity, Mahafaly Plateau, spiny forest, sexual color dimorphism, soil arthropod.

Wesener T. 2020. Dichromatobolus, a new genus of spirobolidan millipedes from Madagascar (Spirobolida, Pachybolidae). European Journal of Taxonomy 720: 107-120. https://doi.org/10.5852/ejt.2020.720.1119

\section{Introduction}

Madagascar, the large island off the eastern coast of Africa, is famous for being a biodiversity hotspot (Myers et al. 2000), as well as a center of endemism for numerous animal and plant groups (Goodman \& Benstead 2005; Pearson \& Raxworthy 2009). Because of differences in rainfall and altitude (Battistini 1972; Jury et al. 1995; Dewar \& Richard 2007), Madagascar hosts several different ecosystems, from spiny dry forests to montane rainforests (Moat \& Smith 2007), probably the main drive behind an extraordinary species richness in several groups of organisms. Millipedes (class Diplopoda de Blainville, 1844) are no exception, with most known species being endemic to Madagascar (Enghoff 2003), and numerous known microendemic species (Wesener \& Sierwald 2005; Wesener 2009; Wesener et al. 2014; 
Moritz \& Wesener 2017). Only six of the 16 (Blanke \& Wesener 2014) orders of the Diplopoda are known with indigenous described species from Madagascar, but two more, Polyzoniida Gervais, 1844 (Wesener 2014a) and Siphonophorida Newport, 1844 (Wesener 2014b), are present with indigenous, but still undescribed species. Especially rich in genera and species on Madagascar is the family Pachybolidae Cook, 1897 sensu Hoffman 1980 (order Spirobolida Cook, 1895) (Wesener et al. 2009). Altogether 15 of the 16 indigenous genera of the Spirobolida on Madagascar belong to the Pachybolidae, with only Hylekobolus Wesener, 2009 belonging to the family Spirobolellidae Brölemann, 1913. With 15 currently described genera, Madagascar is also one of the main centers of diversity of the Pachybolidae globally, a family showing a Gondwanan distribution (Enghoff et al. 2015). The relationships of the Malagasy genera of the Pachybolidae are still unclear. One genus, Madabolus Wesener \& Enghoff, 2008, occurring in western Madagascar is clearly, based on morphological (Wesener et al. 2008) and genetic characters (Pitz \& Sierwald 2010), a member of the tribe Pachybolini Wesener \& Enghoff, 2008, which is further distributed in western and eastern Africa. Another genus Spiromimus de Saussure \& Zehntner, 1901, diverse in dry forests and rainforests in the northern half of Madagascar, shows some morphological similarities with the genus Xenobolus Carl, 1919 from southern India (Wesener \& Enghoff 2009). The relationships of the other 13 genera of the Pachybolidae endemic to Madagascar are still unclear and might be only resolved with a comprehensive molecular study including other genera from South America, South Africa, India, Southeast Asia and Australia. At the species level, many species of Pachybolidae are restricted to very small areas of distribution (e.g., Wesener 2011; Wesener et al. 2011), and 25 of the 58 known endemic species are listed in one of the top three IUCN Red List categories (e.g., Rudolf \& Wesener 2017a, 2017b, 2017c, 2017d).

Here we describe a new genus from Madagascar, based on a new species from the southwestern spiny bush featuring unusual morphological characters.

\section{Material and methods}

\section{Institutional abbreviations}

CAS $=$ California Academy of Sciences, San Francisco, USA

CASENT $=$ Entomology collection, California Academia of Sciences, San Francisco, USA

FMNH $=$ Field Museum, Chicago, USA

ZFMK = Zoological Research Museum A. Koenig, Leibniz Institute for Animal Biodiversity, Bonn, Germany

\section{Illustrations}

Dissecting and camera lucida drawings were done under an Olympus SZX12 stereo microscope. For scanning electron microscopy (SEM), the samples were dehydrated via an ethanol chain, mounted on stubs and dried overnight. The stubs were sputter-coated with $100 \mathrm{~nm}$ of gold in a Hummer VI (Anatech, USA) sputtering system. Images were obtained using a Hitachi S-2460 SEM. Multi-layer photographs were taken with a Leica Z6 Imaging-System based at the ZFMK. Stacked images were put together using the software Auto-Montage (Syncroscopy). All images were later modified using Adobe Photoshop version CS2 and assembled into plates using Adobe Illustrator version CS2. The locality of specimens was mapped in the free software DIVA-GIS 7.5.0.0 (Hijmans et al. 2001) on spatial information made freely available by the GADM database 1.0 and the Madagascar Vegetation mapping project (Moat \& Smith 2007).

\section{Collection and deposition}

No specimens were collected by the author, they come mainly from the backlog of the FMNH and CAS. An additional large amount of specimens (from unknown localities) came from the pet trade, both from an import in 2007 by the German firm (now no longer in existence) Odenwald Exoten, and from 
an additional import in 2019 (only males) by the French trader ebugz.eu. Specimens were received for identification and are stored in the public museum collections of the CAS, FMNH and ZFMK.

\section{DNA extraction attempts}

Despite four DNA extractions, and the utilization of PCR protocols which have yielded good sequence data for the Spirobolida (Wesener et al. 2011) and other millipedes (Wesener 2015a, 2015b) in two laboratories, the Field Museum, Chicago, USA and the ZFMK, no good COI barcoding sequences could be obtained. Utilized primer pairs for PCR and sequencing were the HCO/LCO primers (Folmer et al. 1994) and modified degenerated primers, HCO-JJ/LCO-JJ (Astrin \& Stüben 2008). Curiously, something not observed in any of the other Diplopoda COI sequences we analyzed so far, the PCR result showed triple bands, and the sequencing result indicated contaminations.

\section{Results}

Class Diplopoda de Blainville in Gervais, 1844

Order Spirobolida Cook, 1895

Family Pachybolidae Cook, 1897 sensu Hoffman 1980

Dichromatobolus gen. nov.

urn:1sid:zoobank.org:act:2BC93D12-96E1-4ECC-B83D-44249A06E099

\section{Type species}

Dichromatobolus elephantulus gen. et sp. nov. Monotypic.

\section{Diagnosis}

Massive, short, differs from all other known genera of Pachybolidae in mature males being only eight times longer than wide. Coloration uniquely differing between sexes, females grey, males red (Fig. 1A). Transverse ridge on mentum of gnathochilarium absent (Fig. 4A). Male legs with tarsal pads and unusually spinose tarsi (Fig. 4D). Shares anterior telopods with apical process of telopodite (Fig. 4E-F) with Zehntnerobolus Wesener, 2009, from which Dichromatobolus gen. nov. differs strongly in habitus and posterior gonopods. Simple, apically swollen posterior gonopods (Fig. 5A-C) are shared with Corallobolus Wesener, 2009, from which Dichromatobolus gen. nov. differs in habitus and anterior telopods.

\section{Etymology}

After the differences in the color pattern between the sexes, and '-bolus', a common suffix for genus names of the Spirobolida. Masculine.

\section{Taxonomic position}

The posterior gonopods being connected by a sclerotized sternite as well as the absence of apodemes on the anterior gonopods (Fig. 4E-F) place Dichromatobolus gen. nov. in the suborder Trigoniulidea Attems, 1909, family Pachybolidae. The closest relative of Dichromatobolus gen. nov. is unknown.

\section{Remarks}

There is a second potential species, $>100 \mathrm{~mm}$ in length, with specimens from Manongarivo, Ananambao (FMNH-INS 56254), all unfortunately female. Their wide body with short legs and grey color (all other larger Spirobolida genera on Madagascar are black/red, Wesener et al. 2009) might indicate a relationship to Dichromatobolus gen. nov. 


\section{Dichromatobolus elephantulus gen. et sp. nov. urn:1sid:zoobank.org:act:A768C2C3-047C-43A9-8F6B-47EDD40371B4}

Figs $1-6$

\section{Diagnosis}

Body 60-80 mm long, massive, bulky spirobolidan. Epiproct not projecting. Males red, females grey, ozopore openings in both sexes marked by a black circle. Males with tarsal pads, coxa projections absent. Legs and antennae short. Anterior gonopods, telopodite process well-developed and at apex curved laterally. Posterior gonopod slender and elongated, telopodite simple, rectangular, apically with opening of efferent duct.

\section{Etymology}

Elephantulus, diminutive noun in apposition, after the resemblance to an elephant in the female grey color, as well as a hint referring to the width of the species.

\section{Type material}

\section{Holotype}

MADAGASCAR • O’; 65 km E of Itampolo; 2439.02' S, 4357.79' E; 130 m a.s.1.; 10-17 Jan. 2011; M. Irwin, R. Harin Hala leg.; Malaise trap; path in dry forest; CAS MG-54C-78 (CASENT 9068311).

\section{Other material examined}

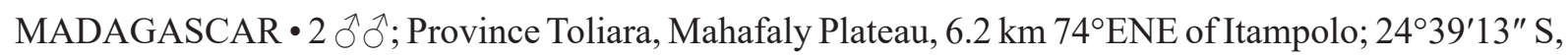
4359'48" E; 80 m a.s.1.;21-25 Feb. 2002; Fisher, Griswold et al. leg.; spiny forest thicket; hand collecting; CAS BLF 5762 (GCKMP-FM-060) 2 우우 Toliara, Atsimo-Andrefena, $13.5 \mathrm{~km}$ SSE of Efoetse, $2 \mathrm{~km}$ E of Soarano village; $24^{\circ} 11.3^{\prime} \mathrm{S}, 4^{\circ} 46.7^{\prime} \mathrm{E}$; $50 \mathrm{~m}$ a.s.1.; 19 Apr. 2005; Voahangy Soarimalala leg.; spiny

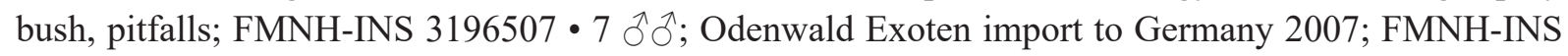
$55888 \bullet 17$ 우; same data as for previous; FMNH-INS 55887• 3 우; same data as for previous; ZFMK

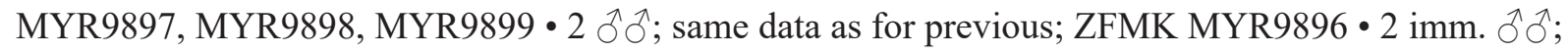
pet trade, ebugz.eu; import to France 2019; ZFMK MYR8708, MYR8745.

\section{Description}

Measurements. Male holotype: $47+0$ body rings, $62 \mathrm{~mm}$ long, $7.7 \mathrm{~mm}$ wide. Widest male (CAS BLF 5762), broken, $8.2 \mathrm{~mm}$ wide. Female (ZFMK MYR9899): $48+0$ body rings, $76 \mathrm{~mm}$ long, $9.0 \mathrm{~mm}$ wide.

Coloration. Sexually dimorphic (Fig. 1A). Male: head and body reddish (Fig. 1A-E), telson bright red (Fig. 1F), ozopores marked by black spot. Legs and antennae black (Fig. 1B-F). Female: Head and body including telson grey (Fig. 1A), ozopores marked by black spot. Posterior margin of body rings darker. Legs and antennae black.

HEAD. In male, each eye with 45-50 ommatidia arranged in 10 vertical rows with: 4, 5, 6, 7, 7, 6, 5, 4, 3, 2 ommatidia, respectively (Fig. 1B, D). Incisura lateralis open (Fig. 1D). Labrum with standard three irregular teeth and single row of 10-12 stout marginal setae (Fig. 1E). Clypeus with two setiferous foveolae on each side. Antennae short, protruding back to ring 3 in males (Fig. 1B). Relative lengths of antennomeres: $1<<2>>3=4>5=6$, second antennomere twice as long as others (Fig. 2A). Terminal antennomere with four large sensory cones located together inside a membranous area (Fig. 2B). Antennomere 5 and 6 latero-apically with sensilla basiconica (Fig. 2C). 

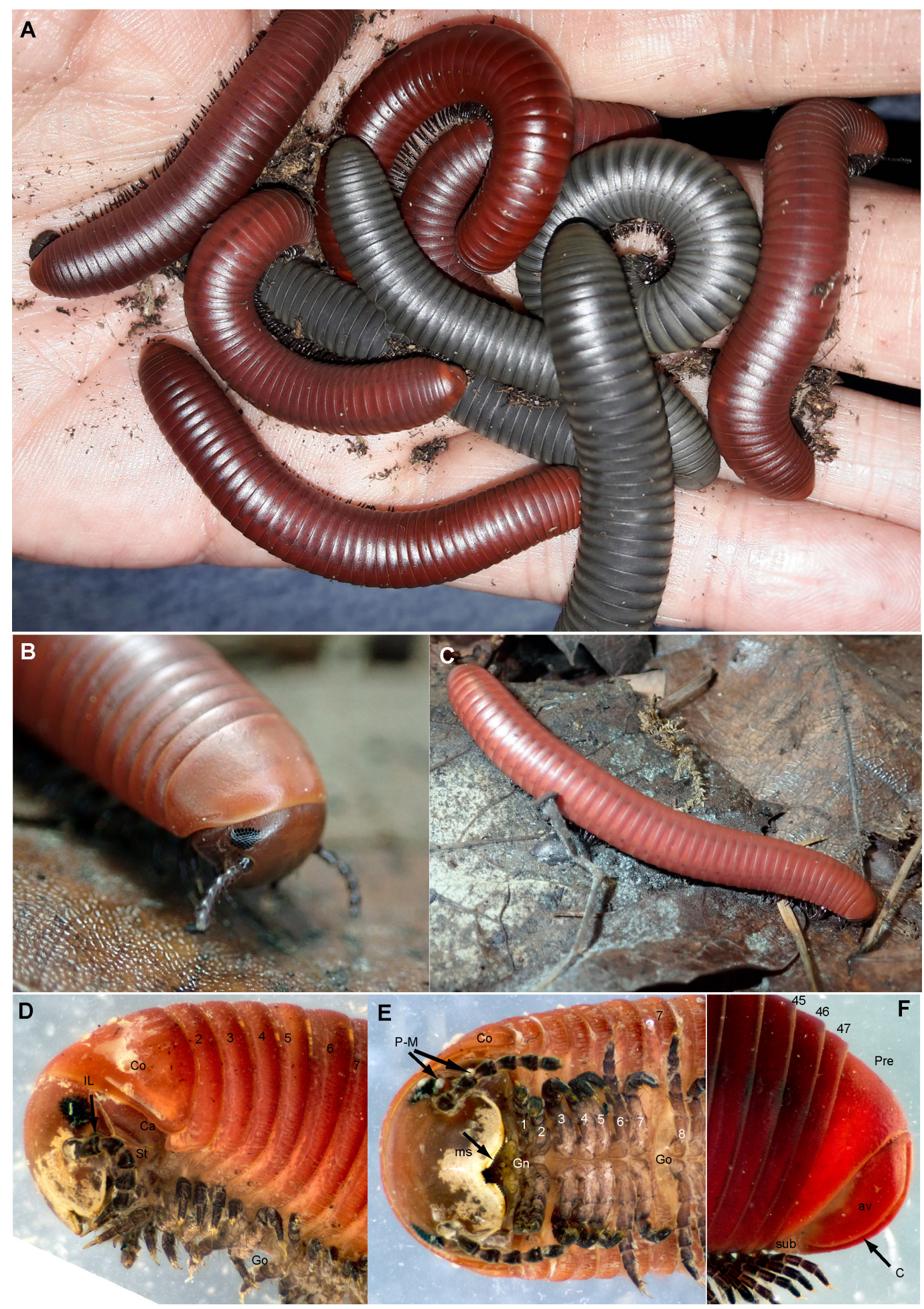

Fig. 1. Dichromatobolus elephantulus gen. et sp. nov. A. Living $\widehat{\partial}$ (red; FMNH-INS 55888) and $\bigcirc$ (grey; FMNH-INS 55887) from Odenwald Exoten 2007 import, photo by P. Decker. B-C. Living immature §, 2019 import (ZFMK MYR8708), photo by L. Moritz. B. Head. C. Whole body. D-F. §ิ (ZFMK MYR8745), multi-layer photographs. D. Anterior body, lateral view; E. Leg pairs 1-7, ventral view. F. Posterior body end with telson. Abbreviations: $\mathrm{av}=$ paraprocts; $\mathrm{C}=$ lips of paraprocts; $\mathrm{Ca}=$ cardines; $\mathrm{Co}=$ collum (ring 1); $\mathrm{Gn}=$ gnathochilarium; $\mathrm{Go}=$ gonopods; $\mathrm{IL}=$ incisura lateralis; $\mathrm{ms}=$ marginal setae; $\mathrm{P}-\mathrm{M}=$ parasitic(?) mites; Pre = epiproct; $\mathrm{St}=$ stipes; $\mathrm{sub}=$ hypoproct. Not to scale. 


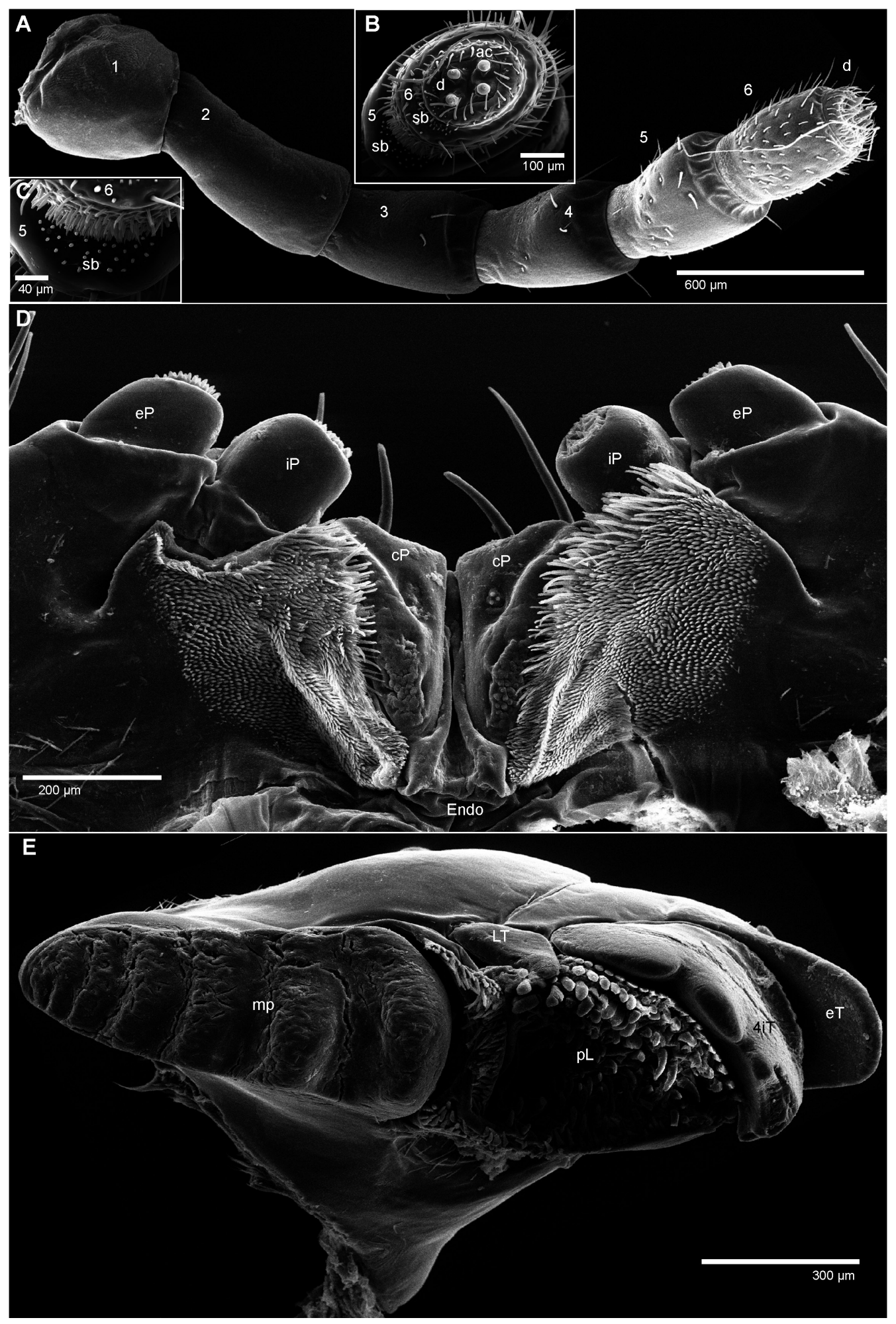

Fig. 2. Dichromatobolus elephantulus gen. et sp. nov., ô (ZFMK MYR9896), SEM. A. Right antenna. B. Disc, apical view. C. Border of antennomere 5 to 6 with sensilla basiconica. D. Gnathochilarium, internal surface. E. Left mandible, mesal view. Abbreviations: $4 \mathrm{iT}=$ four-combed inner tooth; ac $=$ apical cone; $\mathrm{cP}=$ central pads; $\mathrm{d}=$ disc; Endo = endochilarium; $\mathrm{eP}=$ lateral palpus; $\mathrm{eT}=$ external tooth; $\mathrm{iP}=$ inner palpus; $\mathrm{LT}=$ lateral tooth; $\mathrm{mp}=$ molar plate; $\mathrm{pL}=$ pectinate lamellae; $\mathrm{sb}=$ sensilla bascionica; numbers refer to antennomere number. 
GNATHOChILARIUm. Lamellae linguales each with two standard setae located one behind the other. Stipites each with three apical setae. Basal part of mentum not divided, but with several ridges (Fig. 4A). Endochilarium and central pads shaped like in other Spirobolida species (Fig. 2D).

MANDIBLE. In male, stipes with projecting sharp edge (Fig. 1D). Gnathal lobe, external tooth simple, rounded; inner tooth with four cusps (Fig. 2E). Six pectinate lamellae. Mesal margin of pectinate area (intermediate area) with circa four rows of small, slender spines. Molar plate with numerous (8 or 9) transverse furrows (Fig. 2E). Female not investigated.

Collum. Smooth, laterally not protruding as far as ring 2 (Fig. 1B, D).

BODY RINGS. Ozopores marked by black color, starting at ring 6 , located a half diameter before suture between mesozona and metazona. Rings with smooth, but irregular coriaceous surface, ventrally on metazona with transverse ridges. Limbus simple, with cuticular scales and wavy margin (Fig. 3A).

Telson. Paraprocts with weak lips, little micropunctation towards edges (Fig. 1F). Epiproct wellrounded, not protruding above paraproct (Fig.1F). Hypoproct inconspicuous (Fig. 1F).

LEGS. Leg 1 with a large cylindrical coxa, twice as long as other podomeres (Fig. 4C). Tarsus with three pairs of ventral spines, without an apical spine beyond claw. Leg 2 with a strongly elongated coxa, fused to sternite. Tarsus with four pairs of ventral spines and a short apical spine (Fig. 4B). Midbody legs with a rectangular coxa, as long as other podomeres. Each podomere ventrally with a single or a pair of apical setae, tarsus in males with a ventral pad, 6 pairs of ventral and 5 pairs of lateral spines (Fig. 4D). Length of midbody legs circa 0.7 times body diameter in males (Fig. 1E).

\section{Female sexual characters}

Body color grey (Fig. 1A). Female vulva simple, resembling a bivalve shell.
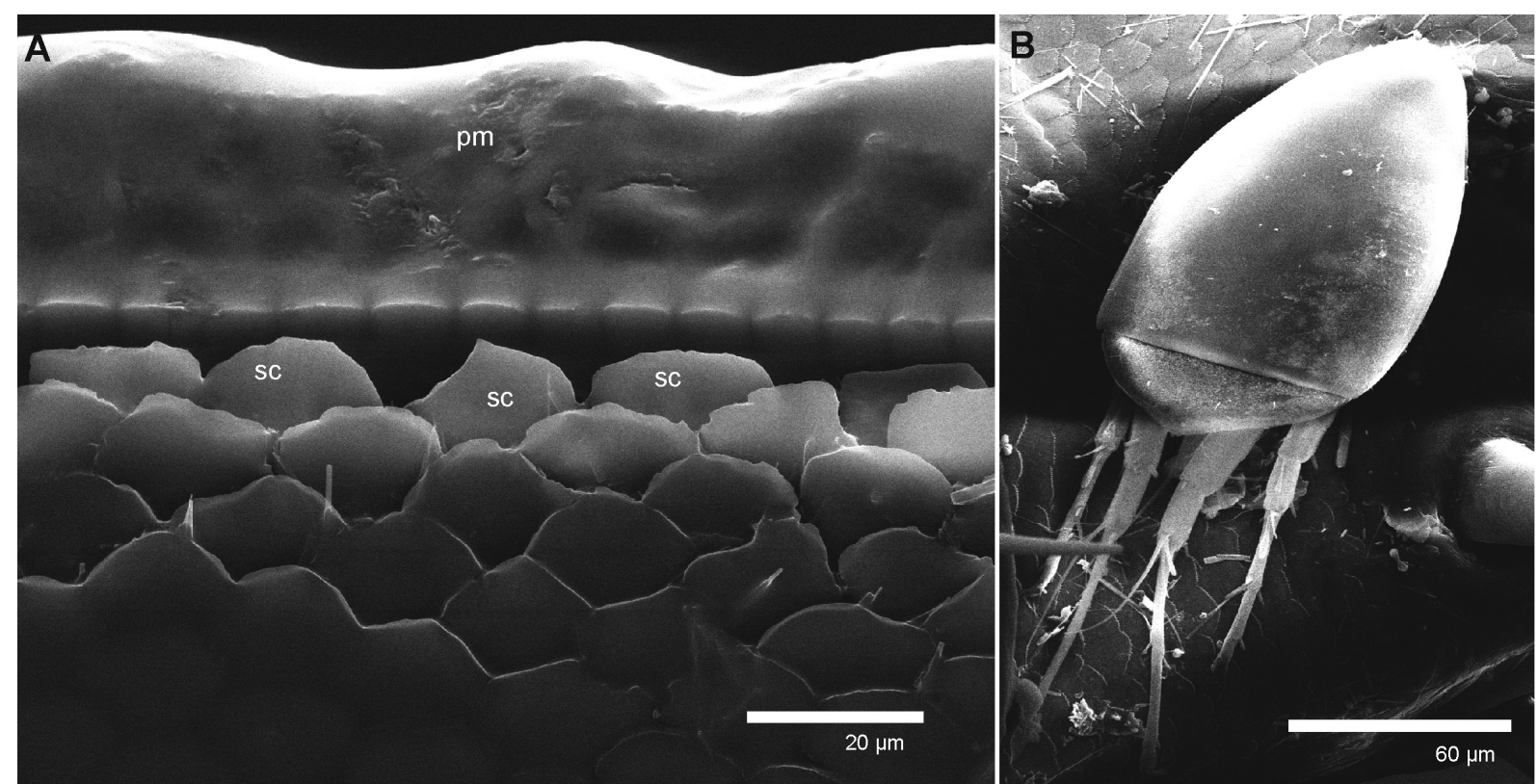

Fig. 3. Dichromatobolus elephantulus gen. et sp. nov., ô (ZFMK MYR9896), SEM. A. Limbus of midbody ring. B. Phoretic(?) mite at body ring. Abbreviations: $\mathrm{pm}=$ tergite margin; $\mathrm{sc}=$ cuticular scales. 


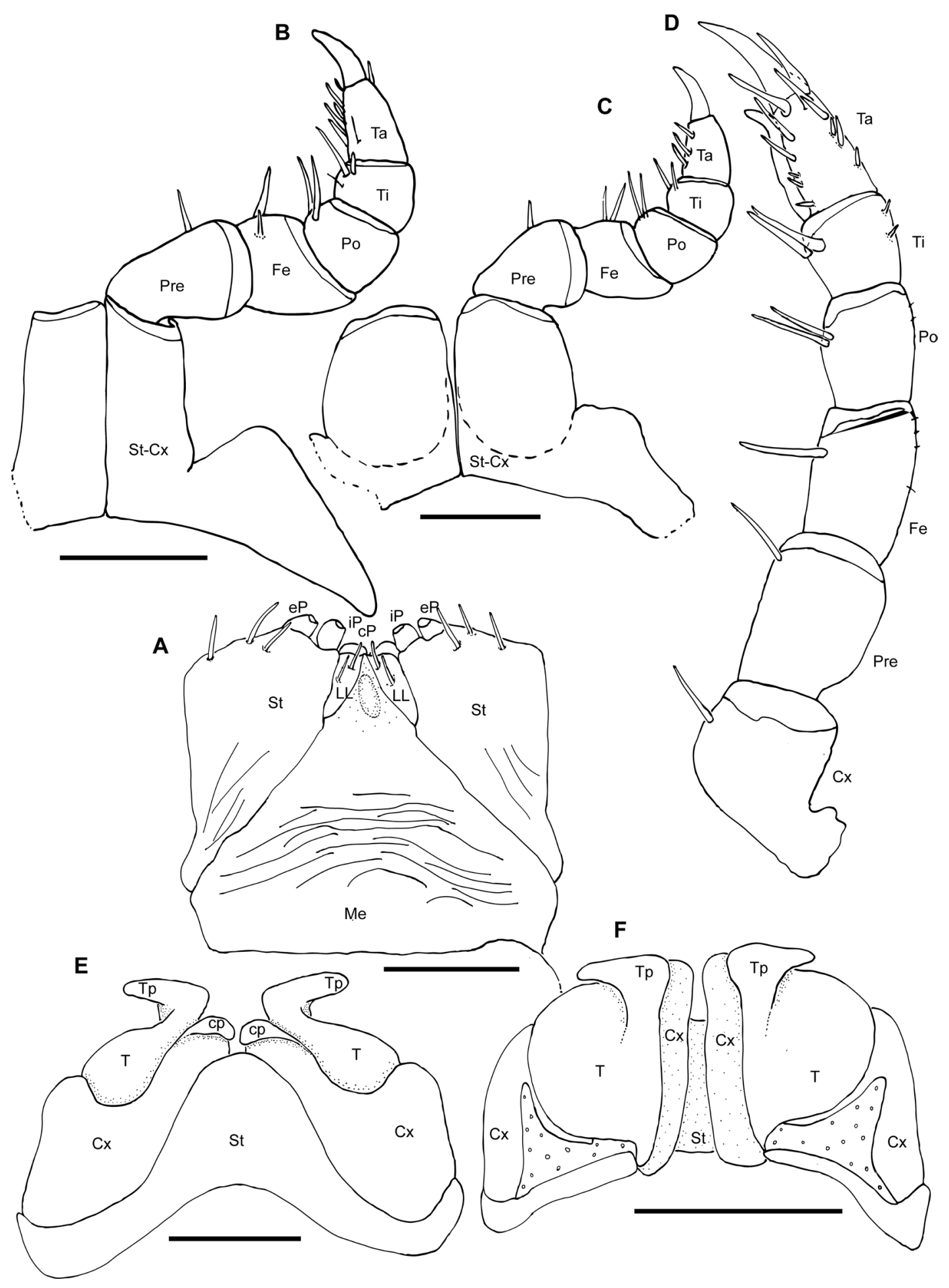

Fig. 4. Dichromatobolus elephantulus gen. et sp. nov., holotype, § (CAS MG-54C-78), drawings. A. Gnathochilarium, ventral view. B. Second leg pair, posterior view. C. First leg pair, posterior view. D. Left midbody leg pair, posterior view. E. Anterior gonopod, anterior view. F. Anterior gonopod, posterior view. Abbreviations: $\mathrm{cp}=$ coxite process; $\mathrm{cP}=$ central pads; $\mathrm{Cx}=$ coxite; $\mathrm{eP}=$ lateral palpus; $\mathrm{Fe}=$ femur; $\mathrm{iP}=$ inner palpus; $\mathrm{LL}=$ lamellae lingualis; $\mathrm{Me}=$ mentum; $\mathrm{Po}=$ postfemur; Pre = prefemur; $\mathrm{St}=$ sternite $; \mathrm{St}-\mathrm{Cx}=$ sterno-coxite $\mathrm{T}=$ telopodite $\mathrm{Ta}=$ tarsus $; \mathrm{Ti}=$ tibia; $\mathrm{Tp}=$ telopodite process. Scale bars $=1 \mathrm{~mm}$. 


\section{Male sexual characters}

Tarsal pads present (Fig. 4D). Coxae 3-7 without coxal processes (Fig. 1E).

Anterior gonopod sternite massive (Fig. 4E), elongated into wide, well-rounded lobe (Fig. 4E), lobe lower than coxite. Sternite in posterior view well-visible, without discernable apodemes. Coxite mesally in anterior view with wide, well-rounded process, apical part of process recessed (Fig. 4E, F). Telopodite with slender process arising mesally (Fig. 4F), process conspicuously curved laterad (Fig. 4E), with well-rounded tip, not reaching lateral margin of telopodite (Fig. 4F).

Posterior gonopods each consisting of two parts, separated by sutures (Fig. 5A-C): (1) basally large, bulky coxite with slender, elongated process of coxite, and (2) apically almost rectangular telopodite with slight membranous folds extending meso-apicad and apicad, efferent duct discharging apically (Fig. 5A-C). Coxal process and telopodite placed in same axis (Fig. 5A-B). Pair of posterior gonopods located parallel to each other, connected by small, sclerotized and visible sternite. Basal part of coxite wide, mesally with small sclerite located on lower level than remaining part (Fig. 5B). Coxite elongated into long coxal process (Fig. 5A). Efferent duct running at mesal margin of coxite (Fig. 5B). Telopodite straight, as wide as coxite process, discharge opening of efferent duct apically. Telopodite shorter than coxite process (Fig. 5A), meso-apically with well-rounded, triangular, membranous process (Fig. 5BC), apically with slightly projecting opening of efferent duct (Fig. 5A-C).

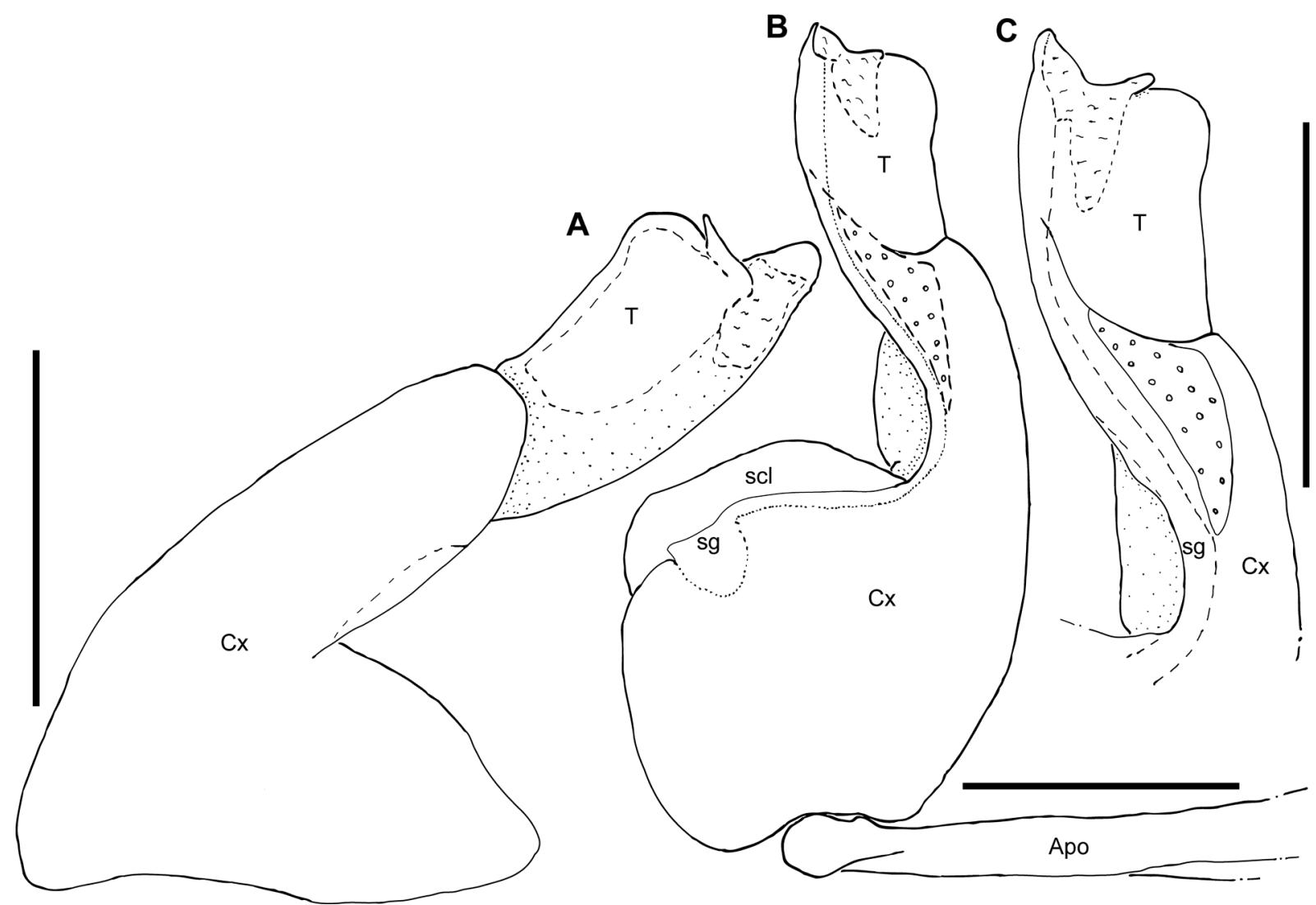

Fig. 5. Dichromatobolus elephantulus gen. et sp. nov., holotype, § (CAS MG-54C-78), left posterior gonopod, drawings. A. Anterior view. B. Posterior view. C. Detail of telopodite, posterior view. Abbreviations: $\mathrm{Apo}=$ apodeme $\mathrm{Cx}=$ coxite $\mathrm{sg}=$ efferent duct; $\mathrm{scl}=$ small mesal sclerite; $\mathrm{T}=$ telopodite Scale bars $=1 \mathrm{~mm}$. 


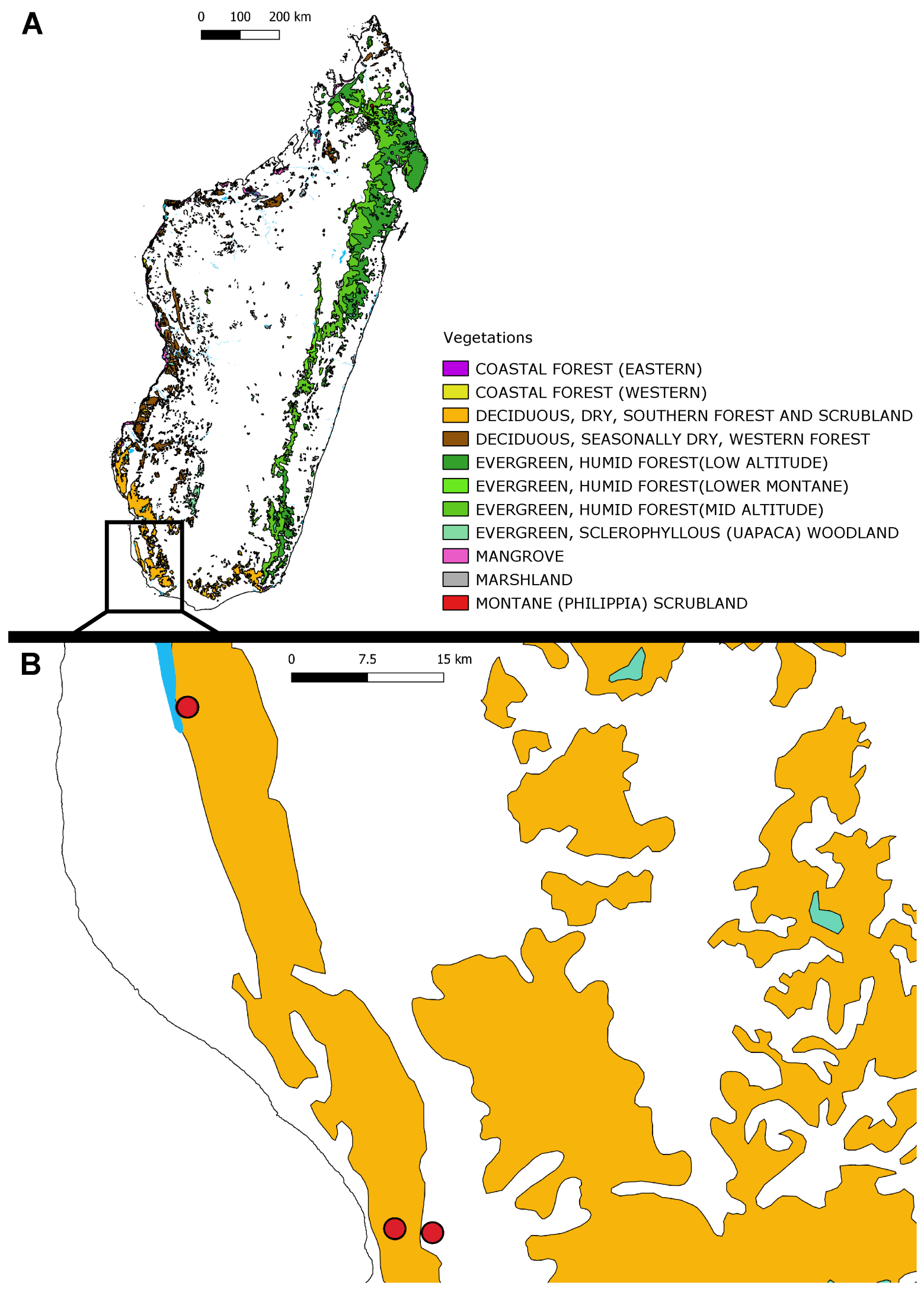

Fig. 6. Distribution of Dichromatobolus elephantulus gen. et sp. nov. Vegetation color marks modified from Moat \& Smith (2007). 


\section{Distribution}

Spiny forests around Toliara in Southwest Madagascar (Fig. 6).

\section{Intraspecific variation}

The three known populations from southwestern Madagascar, as well as the specimens from the pet trade, coming from at least two different imports 2007 and 2019 look very similar to one another, showing only a slight variation in body ring counts, varying between 47 and 48 .

\section{Remarks}

Some element associated with the species, or the surroundings they live in, reacts to ethanol. White crystallizations appear around the specimens and appendages when conserved in ethanol for a longer time.

\section{Discussion}

\section{Life observations}

The fact that this species was part of the pet trade allowed a few life observations. Dichromatobolus elephantulus gen. et sp. nov. did not last long in captivity. Specimens of both the 2007 and the 2019 import died after 2-3 weeks. Males and females of the 2007 import were imported as two different species because of the difference in the color pattern. Such a strong color differences observed between the sexes as in D. elephantulus gen. et sp. nov. have to our knowledge not been reported in any other Juliformia species. Sexual color dimorphism is known for some species of Megaphyllum Verhoeff, 1894 of the related order Julida Brandt, 1833 (Schubart 1934). Also, in the Spirobolida, males are often of a shinier appearance compared to females, as in the African species Epibolus pulchripes (Gerstäcker, 1873), as was illustrated in a recent developmental article (Dhaenens \& VandenSpiegel 2006). In 2019, only males could be observed. Specimens of both sexes were very sluggish, not moving after a disturbance like touching. When moving on the surface they were slow. Digging into loose substrate was as fast as walking on the surface. Specimens of both sexes tried to walk around, not climb up obstacles. Females of the 2007 import were strongly infected with mites, which covered the anterior part of the body and all of the legs. Mites were also present in some of the males (Fig. 3B). The illustrated mite was determined by one of the reviewers as a hypopi, phoretic deutonymphs of acaridian mites.

\section{Outlook}

The discovery of Dichromatobolus gen. nov. shows how little we still know about the diversity of the Pachybolidae on Madagascar, despite the fact that the number of known endemic genera of the island grew from two before 2008 to 16 now. The spiny forest ecosystem, with the great seasonality of rainfall, might make any discovery of surface active millipedes quite difficult, as the roads are difficult to traverse during the rainy season when the millipedes are most likely active on the surface and sexually mature.

\section{Acknowledgements}

I am grateful for the help of Claudia Etzbauer (who did multiple PCR attempts), and for Karin Ulmens' help and advice at the SEM. I thank Peter Decker and Leif Moritz for photographs of living specimens of D. elephantulus gen. et sp. nov. Pooja A. Anilkumar created the map. A study of the millipedes of Madagascar would have been impossible without the collection efforts of Brian L. Fisher and his team (CAS), as well as Steve Goodman and Voahangy Soarimalala (FMNH), for which I am deeply thankful. Our thanks go to Darrel Ubick (CAS), Crystal Maier and Petra Sierwald (FMNH) for the arrangement of the loan of numerous specimens. I am grateful to the two reviewers, Sergei I. Golovatch and one anonymous, as well as the editor Rudy Jocqué, whose comments greatly improved the quality of the here presented work. 


\section{References}

Astrin J.J. \& Stüben P.E. 2008. Phylogeny in cryptic weevils: molecules, morphology and new genera of western Palaearctic Cryptorhynchinae (Coleoptera: Curculionidae). Invertebrate Systematics 22 (5): 503-522. https://doi.org/10.1071/IS07057

Battistini R. 1972. Madagascar relief and main types of landscape. In: Battistini R. \& Richard-Vindard G. (eds) Biogeography and Ecology in Madagascar: 1-5. Springer, Dordrecht. https://doi.org/10.1007/978-94-015-7159-3_1

Blanke A. \& Wesener T. 2014. Revival of forgotten characters and modern imaging techniques help to produce a robust phylogeny of the Diplopoda (Arthropoda, Myriapoda). Arthropod Structure \& Development 43 (1): 63-75. https://doi.org/10.1016/j.asd.2013.10.003

Dewar R.E. \& Richard A.F. 2007. Evolution in the hypervariable environment of Madagascar. Proceedings of the National Academy of Sciences of the United States of America 104 (34): 13723 13727. https://doi.org/10.1073/pnas.0704346104

Dhaenens M. \& VandenSpiegel D. 2006. Contribution to the study of the post-embryonic development and reproduction of the African millipede Epibolus pulchripes (Gerstäcker, 1873) (Diplopoda, Pachybolidae). Belgian Journal of Zoology 136 (1): 43-51.

Enghoff H. 2003. Diplopoda, Millipedes. In: Goodman S.G. \& Benstead J.P. (eds) The Natural History of Madagascar 1728: 617-627. The University of Chicago Press, Chicago.

Enghoff H., Golovatch S., Short M., Stoev P. \& Wesener T. 2015. Diplopoda - taxonomic overview. In: Minelli A. (ed.) Treatise on Zoology - Anatomy, Taxonomy, Biology. The Myriapoda, Vol. 2 (16): 363-453. Brill, Leiden. https://doi.org/10.1163/9789004188273_017

Folmer O., Black M., Hoeh W., Lutz R. \& Vrijenhoek R. 1994. DNA primers for amplification of mitochondrial cytochrome c oxidase subunit I from diverse metazoan invertebrates. Molecular Marine Biology and Biotechnology 3: 294-299.

Goodman S.M. \& Benstead J.P. 2005. Updated estimates of biotic diversity and endemism for Madagascar. Oryx 39 (1): 73-77. https://doi.org/10.1017/S0030605305000128

Hijmans R.J., Guarino L., Cruz M. \& Rojas E. 2001. Computer tools for spatial analysis of plant genetic resources data: 1. DIVA-GIS. Plant Genetic Resources Newsletter 127: 15- 19.

Hoffman R.L. 1980. Classification of the Diplopoda. Muséum d'Histoire naturelle, Geneva.

Jury M.R., Parker B.A., Raholijao N. \& Nassor A. 1995. Variability of summer rainfall over Madagascar: climatic determinants at interannual scales. International Journal of Climatology 15 (12): 1323-1332. https://doi.org/10.1002/joc.3370151203

Moat J. \& Smith P. 2007. Atlas of the Vegetation of Madagscar. Royal botanic gardens, Kew, Richmond.

Moritz L. \& Wesener T. 2017. Integrative description of two new species of Malagasy chirping giant pillmillipedes, genus Sphaeromimus (Diplopoda, Sphaerotheriida, Arthrosphaeridae). European Journal of Taxonomy 381: 1-25. https://doi.org/10.5852/ejt.2017.381

Myers N., Mittermeier R.A., Mittermeier C.G., da Fonseca G.A. \& Kent J. 2000. Biodiversity hotspots for conservation priorities. Nature 403 (6772): 853-858. https://doi.org/10.1038/35002501

Pearson R.G. \& Raxworthy C.J. 2009. The evolution of local endemism in Madagascar: watershed versus climatic gradient hypotheses evaluated by null biogeographic models. Evolution 63 (4): 959-967. https://doi.org/10.1111/j.1558-5646.2008.00596.x 
Pitz K.M. \& Sierwald P. 2010. Phylogeny of the millipede order Spirobolida (Arthropoda: Diplopoda: Helminthomorpha). Cladistics 26 (5): 497-525. https://doi.org/10.1111/j.1096-0031.2009.00303.x

Rudolf E. \& Wesener T. 2017a. Aphistogoniulus corallipes. The IUCN Red List of Threatened Species 2017: e.T80351408A80351443.

https://doi.org/10.2305/IUCN.UK.2017-1.RLTS.T80351408A80351443.en

Rudolf E. \& Wesener T. 2017b. Granitobolus endemicus. The IUCN Red List of Threatened Species 2017: e.T80580633A80580638.

https://doi.org/10.2305/IUCN.UK.2017-1.RLTS.T80580633A80580638.en

Rudolf E. \& Wesener T. 2017c. Riotintobolus mandenensis. The IUCN Red List of Threatened Species 2017: e.T80580925A80580930.

https://doi.org/10.2305/IUCN.UK.2017-1.RLTS.T80580925A80580930.en

Rudolf E. \& Wesener T. 2017d. Riotintobolus minutus. The IUCN Red List of Threatened Species 2017: e.T80580936A80580952. https://doi.org/10.2305/IUCN.UK.2017-1.RLTS.T80580936A80580952.en

Schubart O. 1934. Tausendfüßler oder Myriapoda. I: Diplopoda. In: Dahl F. (ed.) Die Tierwelt Deutschlands und der angrenzenden Meeresteile. 28: 1-318. Verlag Gustav Fischer, Jena.

https://doi.org/10.1007/BF02337682

Wesener T. 2009. Unexplored richness: discovery of 31 new species of Giant Pill-Millipedes endemic to Madagascar, with a special emphasis on micro-endemism (Diplopoda, Sphaerotheriida). Zootaxa 2097: 1-131. https://doi.org/10.11646/zootaxa.2097.1.1

Wesener T. 2011. Re-discovery after more than a century: a redefinition of the Malagasy endemic millipede genus Zehntnerobolus, with a description of a new species (Diplopoda, Spirobolida, Pachybolidae). Zootaxa 3018: 21-26. https://doi.org/10.11646/zootaxa.3018.1.3

Wesener T. 2014a. Redescription of 'Polyzonium' malagassum, a new synonym of Rhinotus purpureus (Pocock, 1894), with notes about the occurrence of the order Polyzoniida on Madagascar (Diplopoda). Zootaxa 3790 (4): 587-594. https://doi.org/10.11646/zootaxa.3790.4.7

Wesener T. 2014b. First records of the order Siphonophorida from Madagascar and Mauritius (Diplopoda). Revue Suisse de Zoologie 121 (3): 415-423.

Wesener T. 2015a. No millipede endemics north of the Alps? DNA-Barcoding reveals Glomeris malmivaga Verhoeff, 1912 as a synonym of G. ornata Koch, 1847 (Diplopoda, Glomerida, Glomeridae). Zootaxa 3999 (4): 571-580. https://doi.org/10.11646/zootaxa.3999.4.7

Wesener T. 2015b. Integrative redescription of a forgotten Italian pill millipede endemic to the Apuan Alps_-Glomeris apuana Verhoeff, 1911 (Diplopoda, Glomerida, Glomeridae). Zootaxa 4039 (2): 391400. https://doi.org/10.11646/zootaxa.4039.2.11

Wesener T. \& Enghoff H. 2009. Revision of the millipede subfamily Spiromiminae, a Malagasy group with Indian connections? (Diplopoda Spirobolida Pachybolidae). Tropical Zoology 22 (1): 71-120.

Wesener T. \& Sierwald P. 2005. New giant pill-millipede species from the littoral forest of Madagascar (Diplopoda, Sphaerotheriida, Zoosphaerium). Zootaxa 1097: 1-60.

https://doi.org/10.11646/zootaxa.1097.1.1

Wesener T., Enghoff H. \& Wägele J.W. 2008. Pachybolini - a tribe of giant Afrotropical millipedes: arguments for monophyly and the description of a new genus from Madagascar (Diplopoda: Spirobolida: Pachybolidae). Invertebrate Systematics 22: 37-53. https://doi.org/10.1071/IS07008 
Wesener T., Enghoff H. \& Sierwald P. 2009. Review of the Spirobolida on Madagascar, with descriptions of twelve new genera, including three genera of 'fire millipedes' (Diplopoda). ZooKeys 19: 1-128. https://doi.org/10.3897/zookeys.19.221

Wesener T., Raupach M.J. \& Decker P. 2011. Mountain refugia play a role in soil arthropod speciation on Madagascar: a case study of the endemic giant fire-millipede genus Aphistogoniulus. PLoS ONE 6 (12): e28035. https://doi.org/10.1371/journal.pone.0028035

Wesener T., Minh-Tu Le D. \& Loria S.F. 2014. Integrative revision of the giant pill-millipede genus Sphaeromimus, with the description of seven new species (Diplopoda, Sphaerotheriida, Arthrosphaeridae). ZooKeys 414: 67-104. https://doi.org/10.3897/zookeys.414.7730

Manuscript received: 12 June 2020

Manuscript accepted: 20 August 2020

Published on: 12 October 2020

Topic editor: Rudy Jocqué

Desk editor: Radka Rosenbaumová

Printed versions of all papers are also deposited in the libraries of the institutes that are members of the EJT consortium: Muséum national d'histoire naturelle, Paris, France; Meise Botanic Garden, Belgium; Royal Museum for Central Africa, Tervuren, Belgium; Royal Belgian Institute of Natural Sciences, Brussels, Belgium; Natural History Museum of Denmark, Copenhagen, Denmark; Naturalis Biodiversity Center, Leiden, the Netherlands; Museo Nacional de Ciencias Naturales-CSIC, Madrid, Spain; Real Jardín Botánico de Madrid CSIC, Spain; Zoological Research Museum Alexander Koenig, Bonn, Germany; National Museum, Prague, Czech Republic. 